International Journal of Solar Thermal

Vacuum Engineering

\title{
Modern eminence and concise critique of solar thermal energy and vacuum insulation technologies for sustainable low-carbon infrastructure
}

\author{
Saim Memon ${ }^{1,}{ }^{*}$, Takao Katsura2 ${ }^{2}$, Ali Radwan ${ }^{2,3}$, Shanwen Zhang ${ }^{4}$, Ahmed A. Serageldin ${ }^{2,3}$, Essam M. \\ Abo-Zahhad ${ }^{5}$, Sergeev Sergey ${ }^{6}$, Abdul Rashid Memon ${ }^{7}$, Sajjad Wali Khan ${ }^{8}$, Siliang Yang ${ }^{9}$, Hussain \\ Haji Jama ${ }^{10}$, Siamak Hoseinzadeh ${ }^{11}$, Ira Devi Sara ${ }^{12}$, Yueping Fang ${ }^{13}$, Leonid Danilevski ${ }^{14}$, Ruslan \\ Isaev ${ }^{15}$, Adnan Kiani ${ }^{16}$
}

1 Solar Thermal Vacuum Engineering Research Group, London Centre for Energy Engineering, School of Engineering, London South Bank University, London, United Kingdom

Division of Human Environmental Systems, Faculty of Engineering, Hokkaido University, Sapporo, Japan

3 Mechanical Power Engineering Department, Faculty of Engineering, Mansoura University, El Mansoura, Egypt

4 College of Mechanical Engineering, Yangzhou University, Yangzhou, China

Mechanical Power Engineering Department, Faculty of Energy Engineering, Aswan University, Aswan, Egypt

Nizhny Novgorod State Technical University, Nizhny Novgorod, Russia

Department of Civil Engineering, Faculty of Engineering Science \& Technology, Ziauddin University, Karachi, Pakistan

Department of Civil Engineering, University of Engineering \& Technology, Peshawar, Pakistan

Built Environment, University of New South Wales (UNSW), Australia

10 Department of Mechanical and Manufacturing Engineering, University of Nairobi, Kenya

11 Centre for Asset Integrity Management, University of Pretoria, Pretoria, South Africa

12 Electrical and Renewable Energy System Research Centre, Department of Computer and Electrical Engineering, Faculty of Engineering, Syiah Kuala University, Darussalam Banda Aceh, Indonesia

13 Coventry University, School of Energy, Construction and Environment, Coventry, United Kingdom

14 State Enterprise, Institute of Housing, NIPTIS, Minsk, Republic of Belarus

15 Department of Renewable Energy Sources, Kyrgyz State Technical University named after I. Razzakov, Kyrgyzstan

16 Department of Computer Science \& Electronic Engineering, University of Essex, Essex, United Kingdom

\section{ABSTRACT}

A concise critique on harnessing the abundant solar thermal energy and improvement with vacuum insulation for the utilization and conversion is presented. This research implicates that the world is becoming a global solar smart city prompted by increasing daily demand of energy by the global population and land-use. Amongst all the renewable energy resources available, solar thermal energy collectors (STC) are the most copious because it is accessible in both direct and indirect modes with global solar thermal capacity in operation in 2019 was $479 \mathrm{GWth}$ and annual energy yield estimated to be $389 \mathrm{TWh}$. Hybridization has been found to be the only way of improving the existing performance of (STC) such as hybrid photovoltaic thermal (PVT) with phase-change material (PCM) for energy storage and magneto-thermoelectric generators (MTEGs) and/or vacuum insulated TEG (VTEG) for waste heat energy conversion to electrical power. The concentrating solar power (CSP) technologies were also precisely studied and yet parabolic trough collector, dish sterling and solar tower are amongst the top solar thermal heat energy harvesters and its electrical power generation has also been comprehended. The modern eminence of vacuum insulation technologies on thermal comfort and sound insulation in sustainable low-carbon buildings is presented. The research implicates that there is still a scope of improving the building and construction sector and target to achieve not only zero-energy buildings (ZEB) but generating-energy buildings (GEB). A concise critique on vacuum insulated smart glazed windows is presented and the review implicates that the hybridization with PV and TEG and novelty in the constructional materials of vacuum glazing (VG) and translucent vacuum insulation panel (TVIP)

\footnotetext{
* Corresponding author.

E-mail address: S.Memon@lsbu.ac.uk
}

https://doi.org/10.37934/stve.1.1.5271 
are vital in the realistic move towards the GEB. The future of vacuum insulation is not only limited to GEB but vital applications occur in medical, imaging, mechatronics and manufacturing industries.

\section{Keywords:}

Solar Thermal Collector; Concentrated

Solar Power; Vacuum Glazing;

Translucent Vacuum Insulation Panel;

Sustainability

Copyright $\odot 2020$ PENERBIT AKADEMIA BARU - All rights reserved

\section{Introduction}

Climate change and global warming are being the research frolicking fields for decades with a drive of curbing-intervention with progressive cutting-edge technologies. However, according to critical appraisal by NASA and NOAA [1], the global mean surface temperature in year 2019 is the top second heated year since, the modern distinction of accounting began in, 1880. Conversely, an increase of $0.98^{\circ} \mathrm{C}$ average-global surface temperature compared to the 1951-1980 was recorded. Figure 1 shows the mean surface temperatures change of year 1880-1884 compared to year 20142018. Contrarywise, it is fair to critique that the global warming and progresses have little influence on the rise of advanced cutting-edge technologies. It can be argued that the modernization and expansion of technological infrastructure could have been a factor. Nevertheless, the first quarter of 2020 has improved the global air quality, $\mathrm{CO}_{2}$ and $\mathrm{NO}_{2}$ emissions but at the cost of Pandemic COVID19 [2]. It has never been easier in projecting the future climate change, such as world's fossil fuels depletion argument might be outdated with carbon-capture and storage (CCS) [3] and would still bring repercussions of air pollution on human health. Irrespective of global warming, a progress in harnessing natural solar thermal energy will rise and the performance of energy conversion and utilization require progressive vacuum insulation technologies to convalesce the global infrastructure, this can be triumphed by disenthralling our self from the existing semantics and methodologies.

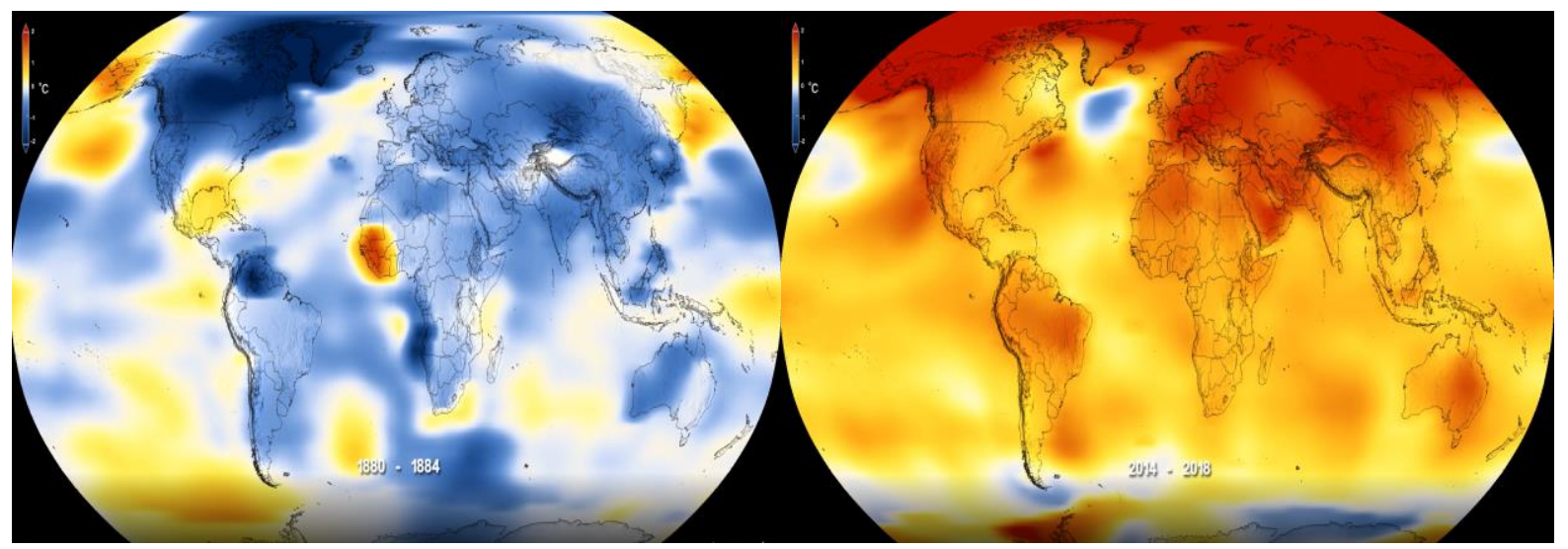

Fig. 1. NASA' global mean surface temperatures change in year 1880-1884 (left) compared to year 2014-2018 showing a rise of $0.98^{\circ} \mathrm{C}[1]$

The compulsion to reduce $\mathrm{CO}_{2}$ emissions, in order to avoid avertable climate change, has also have a relation to address a solemn serious contest in the energy field of squaring the gap between the peak demand and generating capacity. For this, substantial progresses have already been made in the area of solar thermal energy and/or renewable energy sector. For example: (a) the advancements in the field of materials in improving the electrical power efficiency of the solar thermal collectors (STC) and hybridization with photovoltaics (PV) modules (PVT), (b) the 
advancements in the design and development of the concentrated solar power (CSP) systems in improving the thermal energy efficiency that subsequently improve the electrical power efficiency, (c) the advancement in the materials and the design of the smart vacuum glazing and translucent vacuum insulation panels with hybridization of transparent PV would revolutionize the building and construction sector. Moreover, a significant research is being done on the applied vacuum science to smart intelligent windows along with CSP and PV technologies. In recent years, PVT hybrid technologies have been so popular and is growing to be more popular but there are significant challenges in having a clear view on their conversion efficiencies, stability and limitations. Whilst the use of power electronics in effectively transmitting, controlling, converting and monitoring the generating power to the interconnected systems, on-grid and off-grid system integrations play significant role in the electrical power industry. The research problem primarily is to critically and succinctly analyse the reported solar thermal energy and vacuum insulation technologies such as STC, CSP, vacuum insulation and smart vacuum insulated glazing systems. In spite of having a number of advancements in the solar thermal energy and vacuum insulation sector and exaggeration of the benefits of the individual systems in the research community, there is a significant scope of comprehensively and critically analysing the realistic challenges which is the focus of this research paper.

The modern eminence of the world in becoming a global solar smart city prompted by increasing daily demand of energy by the global population. Energy requirements and the related services are indispensable in order to satisfy the mounting social, economic, welfare and health concerns. The adoption of the abundant solar thermal energy resources is inevitable but it comes with the forwardthinking approach of interdisciplinary and multidisciplinary research and is a vital step toward meeting the energy demands for the future generations. Although, it is indeed an overwhelming need that currently approximately 1.4 billion population in the world are in absence of essential electricity supply and more than $80 \%$ of these people reside in rural areas [4]. Harnessing the abundant solar thermal energy $[5,6]$ and improvement with vacuum insulation for the utilization and conversion could not be an arguable issue, but a public perception of bringing sustainability must be valuable. With legislative pressures and growing social awareness of climate change, the global power networks are inclined to include more sustainable generated energy resources, regardless of their effectiveness. With a careful direction, it would be possible to not portray a technology as far more energy-efficient or sustainable than it truly is. However, the challenges remain as low-cost electricity, increasing research business and manufacturing opportunities meaning economic growth whilst maintaining pledges of reducing the impact of creating technologies on global warming. Thus, the main significance of this collaborative paper is not to repeat the existing reviews but to present the modern eminence and concise critique of progressive and realistic solar thermal energy resources and vacuum insulation technologies that have a huge implication and will become the paramount in the energy research fields.

\section{Solar Thermal Energy Harvesting Technologies}

Amongst all the renewable energy resources available, solar thermal energy is the most copious because it is accessible in both direct and indirect modes. It is estimated that the Sun emits solar radiant equivalent power of $3.8 \cdot 10^{20} \mathrm{MW}$. In which, $1.8 \cdot 10^{11} \mathrm{MW}$ is captured by the earth planet, located 150 million $\mathrm{km}$ from the sun, and reached about 60\% [7] on the earth's surface i.e. 1.08.10 ${ }^{11}$ MW and about $40 \%$ of it absorbed in atmosphere and reflected back into the space. If $0.1 \%$ of this solar radiant power were to be converted, at $10 \%$ efficiency, in to electrical power that could be fourfold of the world' total power generating capacity i.e. $3000 \mathrm{GW}$. Solar thermal energy collectors 
have long been used for heating and drying since centuries by ancient civilizations [8]. It is an alternative form of heat exchanger that converts solar irradiations into thermal energy with the use of working fluids (oil, water and/or air) for heating, cooling and electrical power generations.

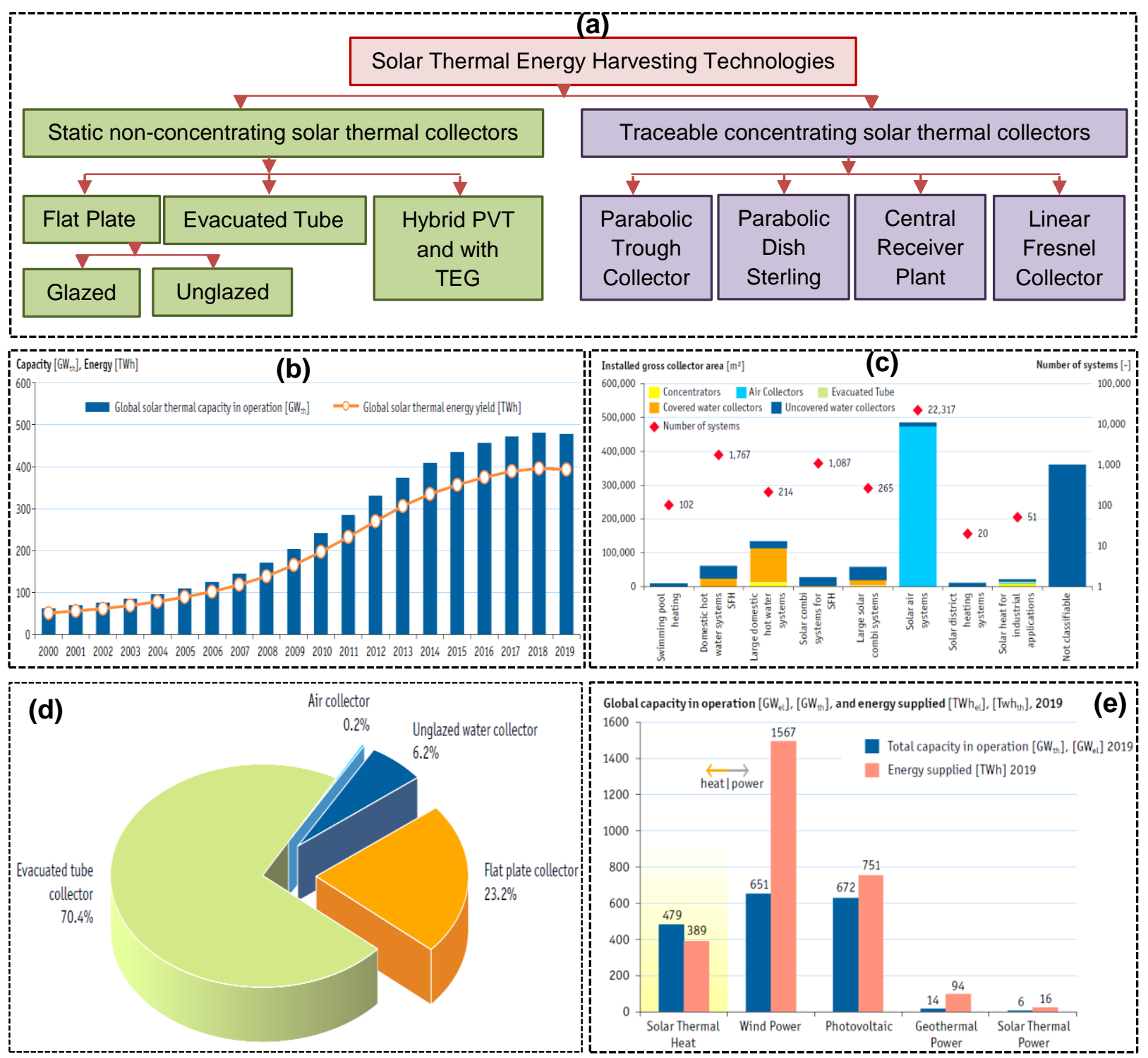

Fig. 2. Shows (a) types of solar thermal energy harvesting technologies, (b) worldwide operational solar thermal energy capacity in $\mathrm{GW}_{\text {th }}$ compared to annual solar thermal energy yield in TWh, (c) worldwide operational PVT systems by solar thermal collector type, area and applications in 2019, (d) global distribution of the operational total installed capacity by solar thermal collector type in 2018, and (e) worldwide operational capacity and annual energy yields of solar thermal heat compared to other renewable energy resources in 2019, IEA SHC \& AEE INTEC] [9]. 
Recently, solar collectors have been advanced and are now characterised, as shown in Fig. 2a, into two types: (a) static non-concentrating solar thermal collectors, it consists of flat plate (glazed and unglazed), evacuated tube, hybrid photovoltaic thermal (PVT); and (b) traceable concentrating solar thermal collectors or famously known as concentrating solar power (CSP), it consists of parabolic trough collector, parabolic dish sterling, central receiver plant and linear Fresnel reflector. According to IEA SHC \& AEE INTEC] [9], the collective global solar thermal capacity in operation by the end of 2019 was $479 \mathrm{GW}_{\text {th }}$ occupied roughly 684 million $\mathrm{m}^{2}$ of area and annual energy yield estimated to be $389 \mathrm{TWh}$ that correlates to the savings of 41.9 Mtoe (million tons of oil equivalent) and/or 135.1 million tons of $\mathrm{CO}_{2}$. Fig. $1 \mathrm{~b}$ shows the global capacity of both unglazed and glazed water collectors in operation increased from $62 \mathrm{GW}_{\text {th }} / 51 \mathrm{TWh}\left(89\right.$ million $\left.\mathrm{m}^{2}\right)$ in year 2000 to $479 \mathrm{GW}$ th/389 TWh (684 million $\mathrm{m}^{2}$ ) in 2019. Fig. 2c shows the PVT systems in operation in 2019 are dominated in the air collector type. Fig. $2 \mathrm{~d}$ shows the worldwide dominance of the evacuated tube collector, estimated to be $70.4 \%$ in 2018 , of the total installed capacity in operation compared to any type. However, Fig. 2e shows that worldwide solar thermal energy potential has not yet been explored compared to wind and PV systems.

\subsection{Static Non-concentrating Solar Thermal Collectors (STC)}

\subsubsection{Flat Plate STC}

Traditionally, flat plate STC are distinguished into unglazed and glazed types. The unglazed flat plate STC has prevalent applications to heating of swimming pools and integration to the building façade due to cost-effectiveness and reasonable collector efficiency. Glazed flat plate STC, as shown in Fig. 3a [10], consists of waterproof-metal casing consists of: dark-painted absorber metal plate supported by insulation layers; inlet-outlet mechanism with flow pipes filled by heat-transfer fluid; and protected by anti-reflective translucent glazing to reduce convective heat and irradiation losses from absorber plate [11]. To critically appraise, glazed flat plate STC are typically limited to the operating temperature range of $30^{\circ} \mathrm{C}$ to $80^{\circ} \mathrm{C}$, if glazing were smashed or fluid froze due to weather conditions then it would be difficult to replace glazing and require regular maintenance. However, it is static and have drawback of non-trackability of solar irradiations. Flat plate STC are usually recommended for hot-arid sunny climate as their performance is distressed by the cold-arid climate and partialized by the weather as moisture and condensation could cause erosion of internal materials.

\subsubsection{Evacuated tube STC}

Evacuated tube STC is considered to be having better thermal performance, operating temperature range of 50C-200C, than the flat plate STC. It is why in 2018 about $70.4 \%$ the global total installed capacity in operation is for evacuated tube STC. Typically, evacuated tube are usually distinguished into either direct heat-flow or heat pipe flow configurations. An evacuated tube, as shown in Fig. 3b [12], constructed with parallel evacuated glass pipes, each evacuated pipe consists of inner and outer tubes (the inner is selectively coated and outer is transparent), with this configuration passive solar tracing would not be an issue. Because, when solar irradiations strike on the outer transparent tube then the inner coated tube absorbs the radiative heat. Here, vacuum plays an important part of minimizing the heat losses and thus require tube to be evacuated with vacuum pump and fused the edges. Such evacuated tube configuration minimizes the convective heat losses, improving thermal insulation, due to the use of vacuum pressure range of (1 $\mathrm{kPa}$ and $10 \mathrm{kPa})$ [13]. However, the convective heat transfer losses can further be supressed with an improvement of tube 
vacuum pressure but it comes with the repercussions of cost and operating temperature limitations.

A number of evacuated tube STC technologies are commercially available and significant research has already been done by numerous authors [12]. For example, as shown in Fig 3b [14,15], a gravityassisted evacuated tube based on heat pipe configuration. In which the solar irradiations (direct and diffuse) warm up the outer surface of the heat pipe evaporator then transferred to the inner surface of the evaporator by conduction and vaporizes the heat pipe working fluid (water). The vaporized water particles flow upwards due to buoyancy forces to the condenser and the header fluid (water) absorbs the heat from the condenser, the condensed water particles move back to the evaporator by gravity and the cycle is repeated [13]. The evacuated tube STC has lower maintenance compared to flat plate STC because if a circular tube gets damaged then the STC will still operate but at lower efficiency and replacing the tube is easier. Evacuated tube STC are primarily suitable for domestic hot water applications. Due to the significance of achieving higher temperatures with evacuated tube STC, overheating has been a problem. But, nowadays, automation and heat energy storage with phase-change materials are also being explored for wider heating and domestic applications. However, evacuated tubes are sensitive and can be improved with nanotechnology, improved glass materials and nanofluids.

\subsubsection{Hybrid PVT STC and with TEG}

The hybrid Photovoltaic Thermal (PVT) STC concurrently convert solar irradiations into electrical power and heat. A conventional PVT STC consists of an absorber plate attached on the bottom of the PV module as shown in Fig. 3c [16]. The heat removal plate lowers the PV module temperature down to its nominal temperature whilst collecting heat to be utilized for domestic hot water applications. It poses a number of challenges as PV modules achieve better efficiency when operated under nominal temperatures, for example every degree rise of temperature above $25^{\circ} \mathrm{C}$, an efficiency of the PV panels could be reduced to $0.25 \%$ for amorphous PV and $0.4-0.5 \%$ for crystalline PV. Fig. $3 c$ illustrates the water-based flat plate PVT STC with glass cover [6]. An imperative recent advance in PVT STC are related to flat plate STC, mostly investigated the tube parameters [17], absorber plate [18], storage size [19], types of PV [20], metal fins [21], fluid flow and passage configurations [22]. Generally, hybrid PVT STC are believed to achieve improved energy conversion efficiency compared to aforementioned types of STC.

The hybrid is a new norm in improving the performance of existing STC. The thermoelectric generator (TEG) can be integrated to the PVT STC to convert the waste heat energy into additional electrical power as shown in Fig. 3d $[23,24]$. The TEG works onto the principle of Seebeck and Peltier effects and it comes with its own limitation in terms of conversion efficiency due to the use of $\mathrm{Bi}_{2} \mathrm{Te}_{3}$ material where advancements have also been reported [25-26]. PVT combi systems utilizes fluids (both water and air) circulation mechanism with semi-transparent PV cells that believed to stable PV cell temperatures and improved overall conversion efficiency as compared to other PVT STC systems. Also, Phase Change Material (PCM) are proposed to PVT STC to improve the overall conversion efficiency during non-daylighting hours. Recently, a number of nano-materials and nanofluid channels proposed $[27,28]$ that improves the cooling mechanism and achieved the electrical efficiency of PVT STC to $19 \%$ utilizing the base fluid as water and $\mathrm{Al}_{2} \mathrm{O}_{3}$ as nano-materials [29-30]. 
2.2 Traceable Concentrating Solar Thermal Collectors (STC) or CSP (concentrating solar power) technologies

2.2.1 Parabolic trough collector (PTC)

(a)

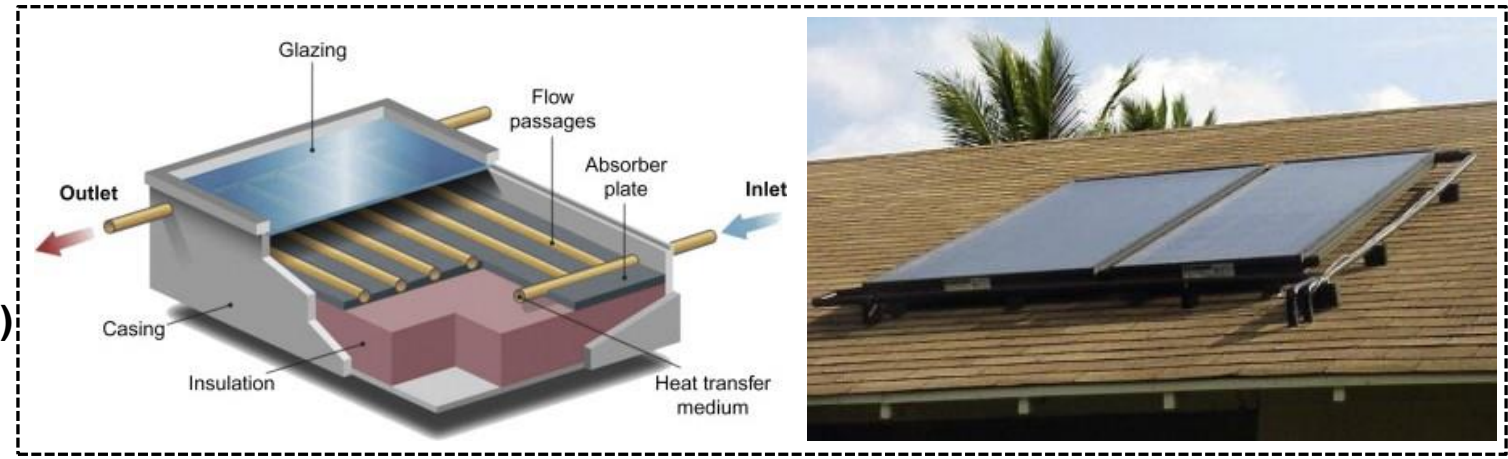

(b)

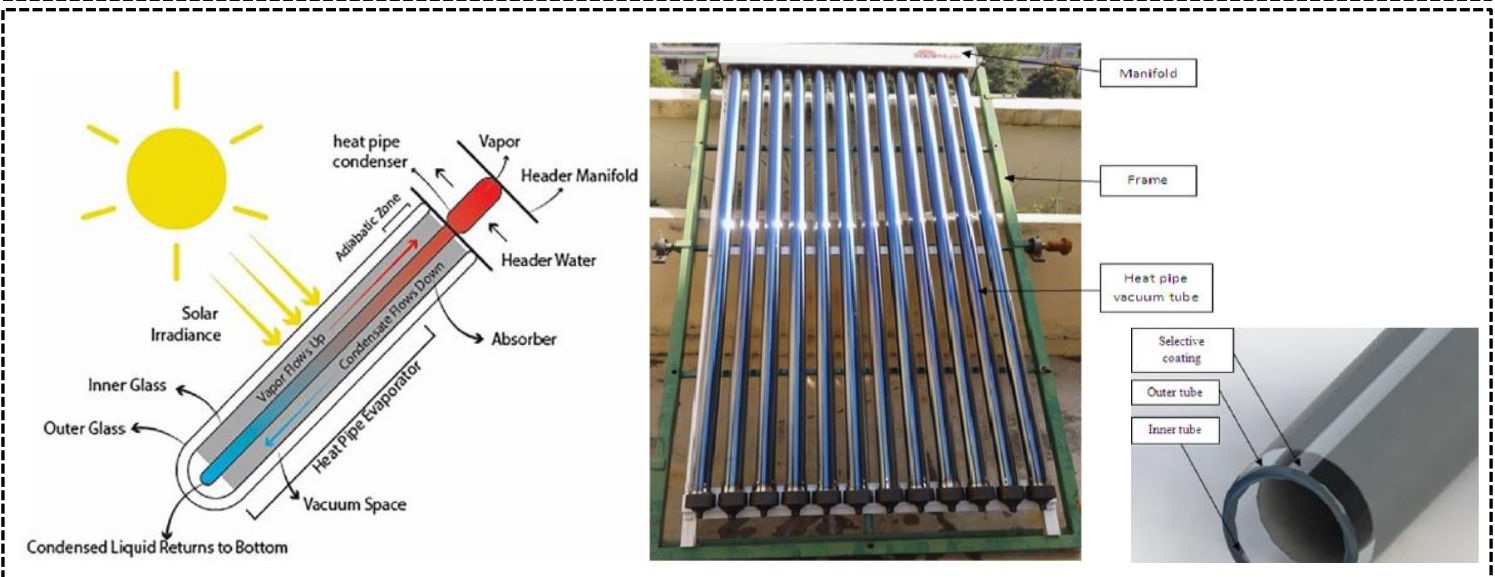

(c)

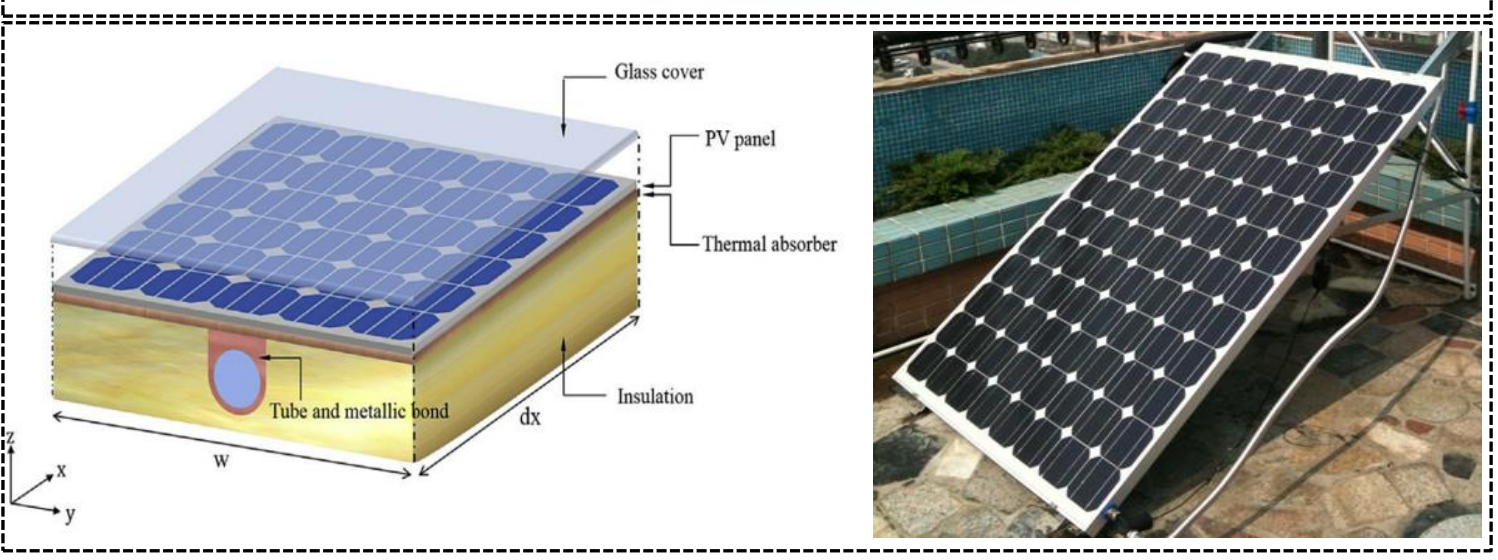

(d)
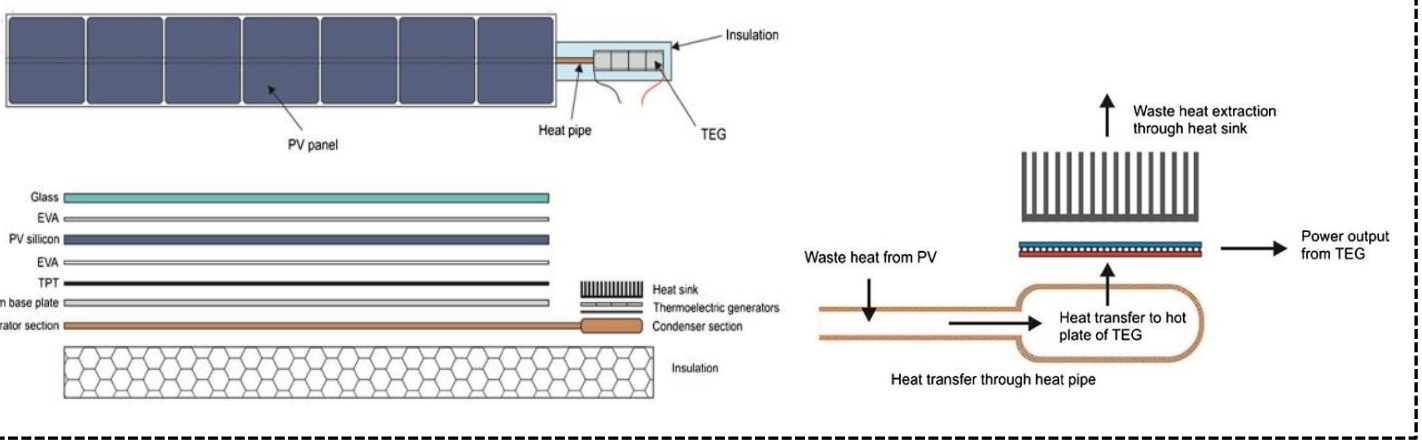

Fig. 3. Illustrates (a) glazed flat plate STC [10], (b) evacuated tube flat plate STC $[12,14,15]$, (c) Photovoltaic/Thermal (PVT) STC [16], and (d) Photovoltaic/Thermal-Thermoelectric Generator (PVT-TEG) STC $[23,24]$ 
Parabolic trough collectors (PTC) equipped with sun-tracking system works on the principle of concentrating solar irradiations, using trough-designed mirrors, on to reflector tubes located in the trough's focal line, as shown in Fig. 4a [31], that heat up the fluid (oil or molten salt) to approximately $400^{\circ} \mathrm{C}[32$ ] and then pumped through a chain of heat exchangers to create superheated steam to be applied on the turbine blades of synchronous generator for the conversion to electrical power. The absorption coefficient and position of the reflector's tube are important parameters for higher solar concentration and heating of the working fluid because it might concentrate to between 70 and 100 times than the usual solar irradiated surface temperature. Typical, solar to electrical power conversion efficiency lies between $10 \%$ and 30\% [33]. The PTC is the most widely used concentrated solar power (CSP) technology for large scale solar thermal power generation. The SEGS (Solar Energy Generating Systems) located in Mojave Desert of California, USA, illustrated in Fig. 4b [34] has the installed capacity of $354 \mathrm{MW}$ and generates $662 \mathrm{GWh}$ of electrical power annually.

\subsubsection{Parabolic dish sterling (PDS)}

The parabolic dish sterling (PDS) has automated sun-tracing system that trace the solar irradiations throughout a day in a clear sky to focus the concentrated heat on the receiver-tube that heat up the fluid to approximately $750^{\circ} \mathrm{C}$ and drives a Stirling engine-generator. It is suitable for lower power generating capacity, typically between $1 \mathrm{~kW}$ and $10 \mathrm{~kW}$ [35], due to the dimensions and balancing weight-load of the dish and the engine. A number of researchers proposed novel designs [36-39], in which the main focus was on the rim angle i.e. near to $45^{\circ}$ believed to achieve higher concentration ratio and some proposed to achieve the flexibility between $10^{\circ}$ and $90^{\circ}$. A typical PDS can achieve concentration ratio up to 2000 times and can achieve efficiency up to $40 \% \mathrm{~A}$ commercial 10 kWe parabolic dish by 'EURODISH' is shown in Fig. $4 b[35,40,41]$.

\subsubsection{Central receiver plant (CRP) or solar tower}

A central receiver plant (CRP) or commonly known as solar town consists of an array of circular traceable mirrors, known as heliostats, utilized to concentrate solar irradiations on to central receiver placed at the high-point of a tower or receiver tube, as schematically shown in Fig. 4c [42]. A receiver absorbs concentrated radiations reflected by heliostats to the receiver tube that heat up the fluid to approximately $1000^{\circ} \mathrm{C}$ heat to be applied on the turbine blades of synchronous generator for the conversion to electrical power. Fig. 4c [43] illustrates a CRP by Gemasolar plant owned by Torresol Energy, Spain, has $19.9 \mathrm{MW}$ installed capacity and can generate $80 \mathrm{GWh}$ electricity annually [43]. A typical CRP can achieve concentration ratio between 300 and 1000 times and the operational efficiency can exceed 30\% [33].

\subsubsection{Linear Fresnel Collector (LFC)}

A linear Fresnel collector (LFC) consists of an array of fixed square shaped mirrors that concentrate solar irradiations to linear Fresnel reflector receiver tube located at the top of the mirrors and simultaneously concentrate the secondary reflected radiation from the secondary reflector to the receiver tube that heat up the fluid up to $400^{\circ} \mathrm{C}$, as illustrated in Fig. $4 \mathrm{~d}$ [44]. LFC is different and cost-effective compared to PTC as it uses a series of flat mirrors with single and double tracing with small curvature instead of the parabolic shaped mirrors. Apart from the land use efficiency, the solar to electric efficiency of LFC is lower compared to PTC due to a reduction in the reflected radiation that reaches the receiver of LFC at high transversal incidence angle because the incidence angle on the LFC varies transversally as well as longitudinally. In nearly most of the receiver 
tube designs, the radiative heat loss dominates in LFC due to larger surface area of the receiver tube. Fig. 4d [45] also shows a typical LFC prototype in Sicily, Italy [46].
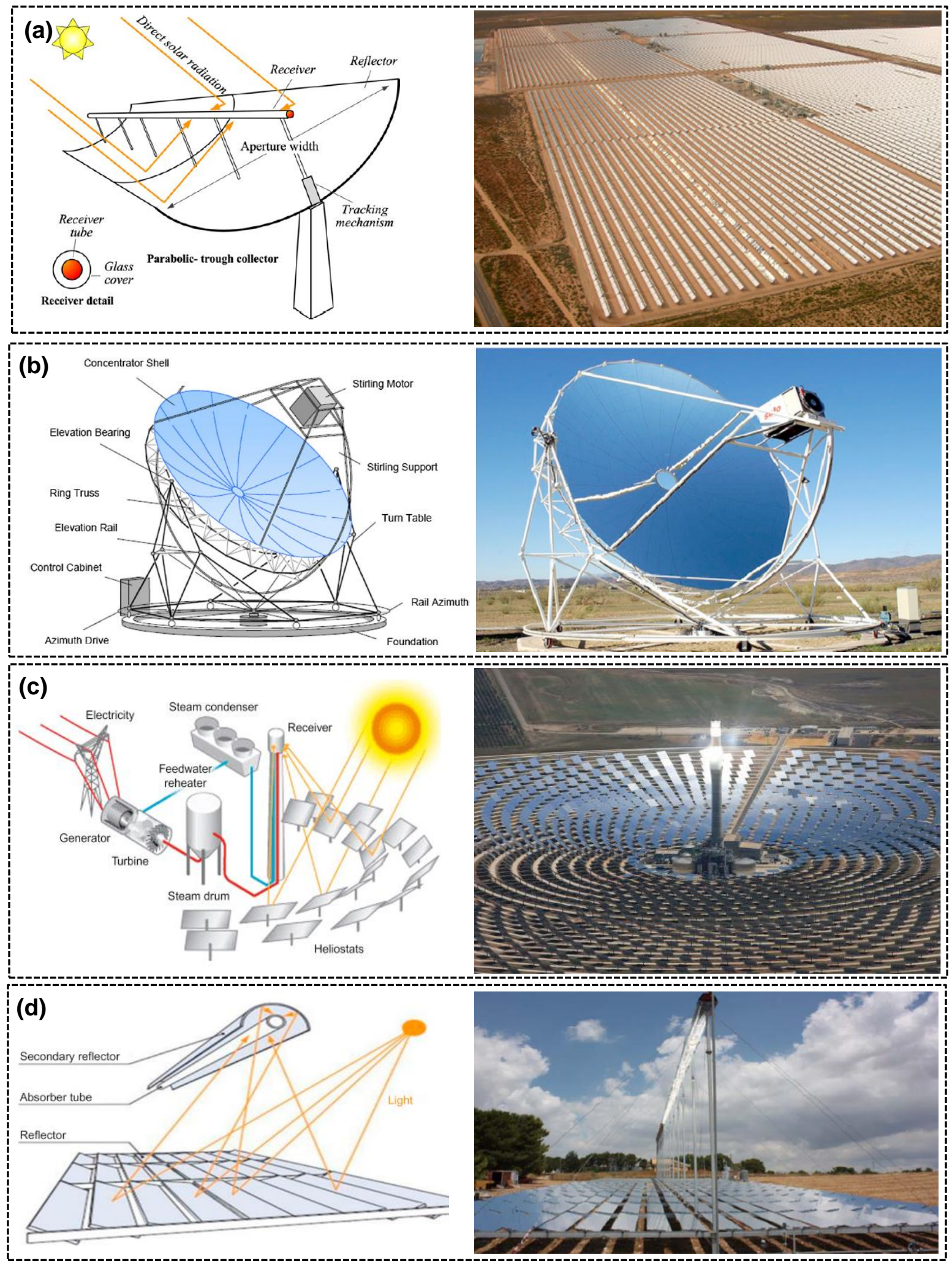

Fig. 4. Illustrates (a) parabolic trough collector (PTC) [31] and the SEGS 354 MW PTC plant in Mojave Desert of California, USA [34], (b) parabolic dish Stirling (PDS) [35] and a typical $10 \mathrm{kWe}$ parabolic dish by 'EURODISH' $[40,41]$, (c) central receiver plant (CRP) [42] and 19.9 MW Gemasolar plant owned by Torresol Energy, Spain, [43], (d) linear Fresnel collector (LFC) [44] and a typical linear Fresnel collector prototype in Sicily, Italy [45,46] 


\section{Vacuum Insulation Technologies}
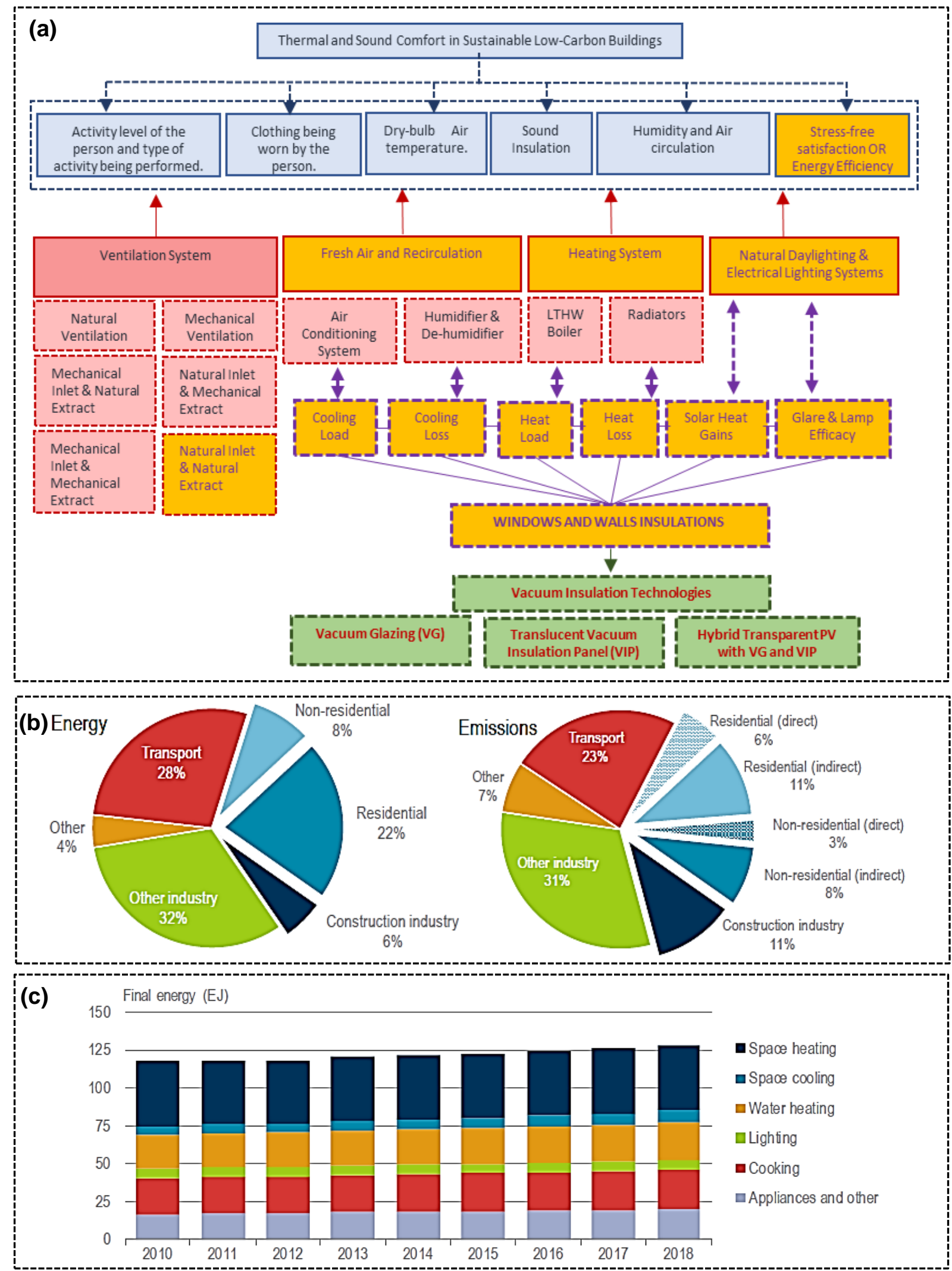

Fig. 5. Illustrates (a) diagram showing the context thermal and sound comfort in sustainable low-carbon building's in relation to the scope of vacuum insulation technologies, (b) global buildings and construction sector's final energy and $\mathrm{CO}_{2}$ emissions in 2018 [47], and (c) the dominance of space heating and space cooling in the building sector [48] 
The modern eminence lies to the health and wellbeing of global population with sustainable lowcarbon infrastructure enabling the current and future generations to flourish. Amongst which thermal and sound comfort is a condition of mind that expresses stress-free satisfaction in the environment of buildings. To achieve this, a string of considerations are needed to take into account, as shown in Fig. 5a, such as: the activity of the person and type of activity being performed, the clothing worn by the person, dry-bulb air temperature, relative humidity, noise pollution or sound insulation, air circulation, and stress-free satisfaction in terms of the tariffs. Thus, an effective ventilation, fresh air and recirculation, heating, cooling, natural daylighting and electrical lighting systems are amongst the vital design considerations in the buildings but comes with implications to the building's heat load, cooling load, heat losses, cooling losses, solar heat gains, glare and lighting efficacy. Within the context and scope of this paper, vacuum insulation technologies have significant influence to minimize the energy consumption and $\mathrm{CO}_{2}$ emissions. In 2018 , worldwide $\mathrm{CO}_{2}$ emissions of $9.7 \mathrm{GtCO}_{2}$ caused from the building sector $[47,48]$. In the global buildings and construction sector's, final energy accounted $36 \%$ and $\mathrm{CO}_{2}$ emissions of $39 \%$ in 2018, as shown in Fig. $5 b$ [47]. As such, space heating and space cooling are amongst the top two contributors, as shown in Fig. $5 c[47,48]$, and thus require intervention of the progressive windows and walls insulation technologies.

\subsection{Vacuum Glazing (VG)}

Vacuum glazing (VG) has a layer of vacuum insulation which is a space, between two glass panes, of reduced mass of atmospheric-air [49]. The rate of decrease of the density of air in a space determines the level of vacuum pressure. This provides thermal insulation, because with a lower density of air the mean free path between air molecules can be increased to above $1000 \mathrm{~m}$ [50], ultimately reduces the heat transfer path between air molecules in a space. This space between two glass panes is usually evacuated to high-vacuum pressure $\left(0.13 \mathrm{~Pa}\right.$ to $\left.1.33 \cdot 10^{-4} \mathrm{~Pa}\right)$ in order to reduce conductive and convective heat transfer [51] to miniscule levels, whilst the heat transfer through radiation can only be minimized using low-emittance coatings [52]. Due to the difference between external atmospheric-air and internal vacuum pressure, spacers are required to prevent the glass panes touching each other [53]. These spacers are called support pillars and typically have radii from $0.1 \mathrm{~mm}$ to $0.2 \mathrm{~mm}$ and height of $0.1 \mathrm{~mm}$ to $0.2 \mathrm{~mm}$ [54]. In VG, even a small vacuum space gives the same thermal insulation because radiative heat transfer is the same at any cavity thickness [55]. A vacuum edge seal around the periphery of the glass panes is required to maintain the high level of vacuum and avoid the problems of gas leaks, degradation of coatings, and absorption of moisture. However, heat transfer through conduction occurs because of the contiguous heat transfer path formed by the support pillar and edge sealing materials. Thus, the constructional components that mainly determines the thermal performance of VG is its vacuum edge seal [56,57]. The vacuum edge seal of a VG must be capable of maintaining a vacuum pressure of less than $0.1 \mathrm{~Pa}$ [58], in order to suppress gaseous conduction, for the expected life of at least 20 years. The edge of two glass panes was first sealed using a high-power laser through a quartz window in a vacuum chamber [59] but the level of vacuum was not less than the required, $0.1 \mathrm{~Pa}$, due to gases and vapour molecules caused by laser sealing technique $[60,61]$. A high-temperature edge sealing material for VG as shown in Fig. $6 a$ [51], Schott solder glass type 8467 at the sealing temperature of $450^{\circ} \mathrm{C}$, was used by the group at the University of Sydney $[51,62,63]$. This technique achieved centre-of-pane thermal transmittance $\left(\mathrm{U}_{\text {centre}}\right)$ value of $0.8 \mathrm{Wm}^{-2} \mathrm{~K}^{-1}$ and subsequently developed to the production level under the trade name of 'SPACIA' in Japan by Nippon Sheet Glass (NSG) [64]. The problems with the high-temperature edge sealing method is that it causes degradation of soft low emittance coatings meaning that only hard coatings can be used [52]. Toughened glass also cannot be used due to the loss of temper at 
high temperatures [65]. Low-temperature solder glass materials were investigated to form a hermetic edge seal, but durability was a problem due to the absorption of moisture. Polymers have problems of both gas permeability and out gassing $[66,67]$. A low-temperature edge sealing material indium or indium alloys melts at about $160^{\circ} \mathrm{C}$ utilized and developed a technique at the University of Ulster, as shown in Fig. $6 \mathrm{~b}[52,68,69]$. This technique achieved a $U_{\text {centre value of } 0.9 \mathrm{Wm}^{-2} \mathrm{~K}^{-1} \text { and }}$ allowed the use of low emittance soft coatings (such as silver), which reduce radiative heat transfer between the glass panes and permits toughened glass pane for an increase of support pillar spacing that reduces conductive heat transfer. The problems with the low-temperature based indium seal are the scarcity and the cost; because of this, the low-temperature indium sealed vacuum glazing process has not yet been commercialised [30]. A recent successful construction of triple vacuum glazing, as shown in Fig. 6e, [71,72,73] and vacuum glazing, as show in Fig. 6c [49,74, 75], invented by $\mathrm{Dr}$ Memon, was based on ultrasonically soldering the primary seal, at low-temperature around $200^{\circ} \mathrm{C}$, made of composite CS-186 or Sn-Pb-Zn-Sb-AITiSiCu in the proportion ratio of 56:39:3:1:1 by wt\% and the secondary seal made of reinforced steel epoxy [72]. This composite hermetically sealed the edges of glass sheets and predicted the $\mathrm{U}$-value of $0.33 \mathrm{Wm}^{-2} \mathrm{~K}^{-1}$ and $0.91 \mathrm{Wm}^{-2} \mathrm{~K}^{-1}$ for triple vacuum glazing and vacuum glazing, respectively. A potential of retrofitting triple vacuum glazing $[76,77,78]$ compared to conventional glazing systems show a promising future [79]. This method overcomes the cost issue, without compromising the scope of using tempered glass and soft coatings, but its composite edge seal has higher percentage of lead $(\mathrm{Pb})$ and it is complex-to-construct, mainly due to the need of precision in ultrasonically soldering the edges of glass sheets $[80,81]$. The novel concept of fusion edge sealed vacuum glazing, as shown in Fig. $6 \mathrm{~d}$, has proved to be cost-effective, energy efficient (ultrasonic soldering free), and Pd-free (hazardous substance free) solution, it has a potential for mass production. It achieved the cavity vacuum pressure of $8.2 \cdot 10^{-4} \mathrm{~Pa}$ and predicted the $U$ value of $1.039 \mathrm{Wm}^{-2} \mathrm{~K}^{-1}$ [57], it has significant potential for mass production.

\subsection{Translucent Vacuum Insulation Panel (TVIP)}

Translucent Vacuum insulation panels (TVIPs), invented by Katsura et al., (2019) [82], is distinguished in terms of its lower thermal conductivity as compared to traditional opaque vacuum insulation panels (VIP) [83,84]. The TVIP in this has been a disruptive innovation to existing insulated windows because it is translucent, slim and can be retrofitted to existing windows of the buildings. This TVIP consists of a hollow-frame structured-core material encapsulated in a transparent multilayered polymeric envelope and the spacers are 3D-printed. The TVIP with frame and mesh spacers achieved centre-of-panel thermal conductivity of $7 \cdot 10^{-3} \mathrm{Wm}^{-1} \mathrm{~K}^{-1}$ at a vacuum pressure of $1 \mathrm{~Pa}$ and the light transmittance of 0.88 .

\subsection{Hybrid Transparent PV with VG and TVIP}

Hybridization is a new way to bring the windows to smart-energy dimension. In this semitransparent CdTe solar cell strings-based glazing is integrated with structured-cored mesh TVIP [85] and VG for a drive toward modernizing smart windows of the buildings as part of the measures for Zero Energy Buildings worldwide $[89,90]$. However, the challenges of voltage quality and harmonic losses remain in the drive for integration of large scale building integrated PV (BIPV) to smart grid and eventually to electric-vehicle charging stations [86,87]. Fig. 6g [88] shows semi-transparent photovoltaic glazing (GPV), vacuum glazing (VG), translucent vacuum insulation panel (GVIP), semitransparent PV with VG (VGPV), and semi-transparent PV with translucent vacuum insulation panel (VIPPV), and their performances were compared. The validated center-of-pane U-values for the VG, 
VGPV, VIPPV, and GPV systems, each with dimensions of $15 \mathrm{~cm} \times 15 \mathrm{~cm}$, are predicted to be $1.3,1.2$, 1.8 , and $6.1 \mathrm{~W} \cdot \mathrm{m}^{-2} \mathrm{~K}^{-1}$, respectively.
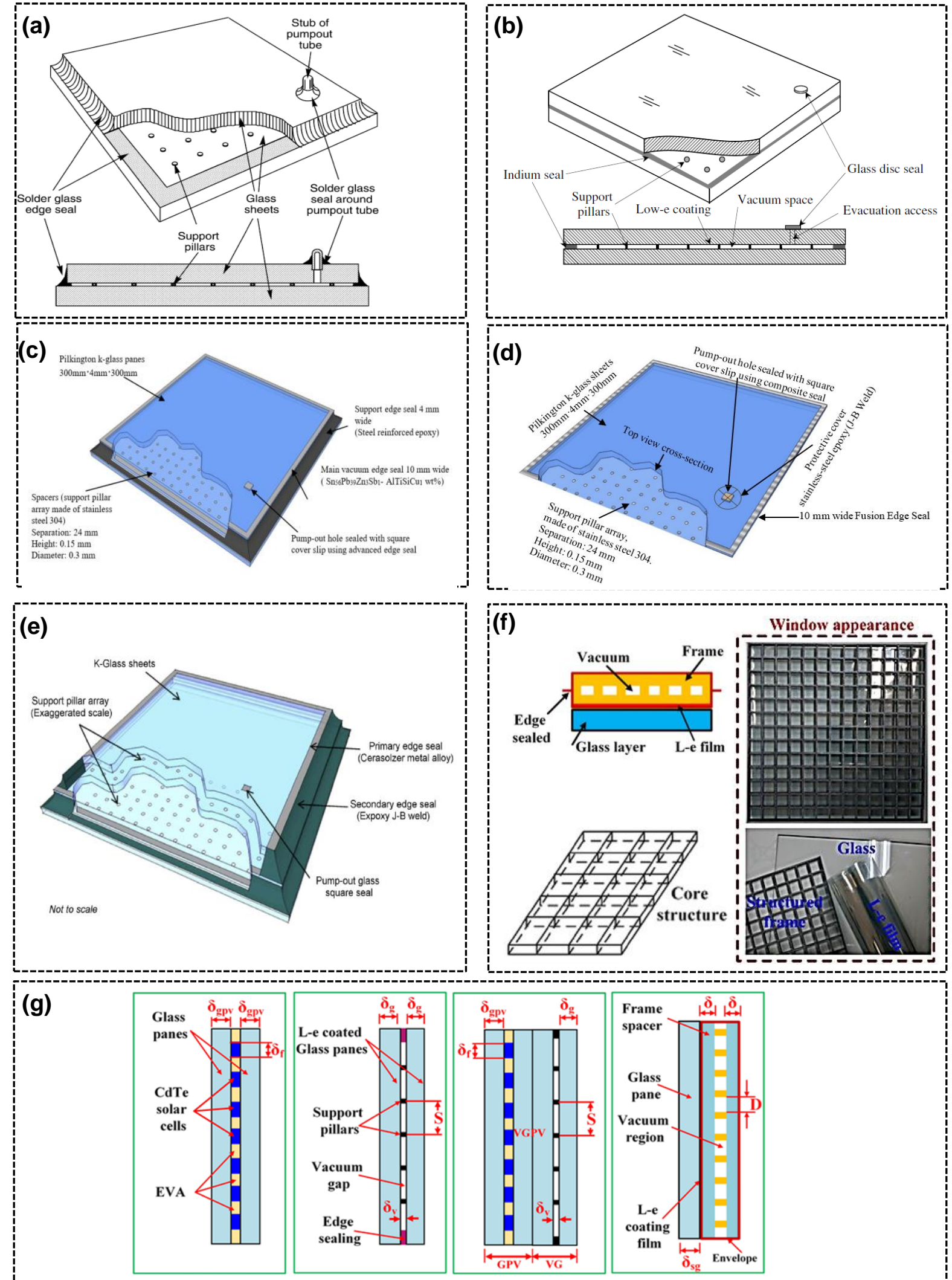

Fig. 6. Schematic diagram of (a) solder-glass sealed VG [51], (b) indium-sealed VG $[52,68,69]$, (c) compositesealed VG, (d) fusion-sealed VG [49], (e) composite sealed TVG [71], (f) structured-core mesh TVIP [82], (g) Hybrid VG, VGPV, VIPPV, and GPV [88] 


\section{Conclusions and Future Research Recommendations}

In this research, a concise critique of the modern eminent solar thermal energy and vacuum insulation technologies are presented. This research implicates that the world is becoming a global solar smart city prompted by increasing daily demand of energy by the global population and landuse. Energy requirements and the related services are indispensable in order to satisfy the mounting social, economic, welfare and health concerns. The adoption of the abundant solar thermal energy resources is inevitable but it comes with the forward-thinking approach of inter and multidisciplinary collaborations and is a vital step toward meeting the energy demands for the future generations. Although, it is indeed an overwhelming need as well that currently approximately 1.4 billion population in the world are in absence of essential electricity supply and more than $80 \%$ of these people reside in rural areas. Harnessing the abundant solar thermal energy and improvement with vacuum insulation for the utilization and conversion have been concisely discussed. The current challenges remain as low-cost electricity, increasing business opportunities meaning economic growth whilst maintaining pledges of reducing the impact of creating technologies on global warming. The main conclusions, along with future research recommendations, are recapitulated into the following two detailed characteristics:

- Amongst all the renewable energy resources available, solar thermal energy collectors are the most copious because it is accessible in both direct and indirect modes with global solar thermal capacity in operation in 2019 was $479 \mathrm{GW}_{\text {th }}$ and annual energy yield estimated to be $389 \mathrm{TWh}$. The worldwide dominance, $70.4 \%$ total installed capacity, of evacuated tube solar thermal collector (STC) was reported. Hybridization has been found to be the only way of improving the existing performance of STC such as hybrid photovoltaic thermal (PVT) that concurrently convert solar irradiations into electrical power and heat for domestic hot water and various applications. The future of PVT STC would be to integrate (or ultra-hybridization) of the phase-change material (PCM) for energy storage and magneto-thermoelectric generators (MTEGs) and/or vacuum insulated TEG (VTEG) for waste heat energy conversion to electrical power. The concentrating solar power (CSP) technologies were also precisely studied and yet parabolic trough collector, dish sterling and solar tower are amongst the top solar thermal heat energy harvesters and significant industrialisation for electrical power generation has also been comprehended. To improve the overall system efficiency of CSP technologies, again ultra-hybridization theories such as the integration of concentrated photovoltaics (CPV) along with wind power and biomass could be explored in the future.

- The scope of vacuum insulation technologies on thermal comfort and sound insulation in sustainable low-carbon buildings is presented. The research implicates that there is still a scope of improving the building and construction sector and target to achieve not only zero-energy buildings (ZEB) but generating-energy buildings (GEB). Because still in 2018 global buildings and construction sector's final energy accounted $36 \%$ and $\mathrm{CO}_{2}$ emissions accounted $39 \%$. A concise critique on vacuum insulated smart glazed windows is presented and the review implicates that the hybridization with PV and TEG and novelty in the constructional materials of vacuum glazing (VG) and translucent vacuum insulation panel (TVIP) are vital in the realistic move towards the GEB. The future of vacuum insulation is not only limited to GEB but vital applications occur in medical, imaging, mechatronics and manufacturing industries. 


\section{Acknowledgement}

This research work was a self-initiated international collaborative move with the authors. It is now, more than ever, important to collaborate worldwide in tackling the global sustainable energy challenges together. This research work was not funded by any grant. All credits of the photographs and diagrams are cited and authors are thankful of impeccable referenced research work in the area of solar thermal energy and vacuum insulation technologies.

\section{References}

[1] NASA Scientific Visualization Studio. "Global Temperature Anomalies from 1880 to 2018." National Aeronautics and Space Administration. Accessed May 25, (2020). https://svs.gsfc.nasa.gov/4626

[2] Dutheil, Frédéric, Julien S. Baker, and Valentin Navel. "COVID-19 as a factor influencing air pollution?." Environmental Pollution (Barking, Essex: 1987) (2020). 10.1016/j.envpol.2020.114466

[3] Scott, Vivian, Stuart Gilfillan, Nils Markusson, Hannah Chalmers, and R. Stuart Haszeldine. "Last chance for carbon capture and storage." Nature Climate Change 3, no. 2 (2013): 105-111. https://doi.org/10.1038/nclimate1695

[4] Owusu, Phebe Asantewaa, and Samuel Asumadu-Sarkodie. "A review of renewable energy sources, sustainability issues and climate change mitigation." Cogent Engineering 3, no. 1 (2016): 1167990. https://doi.org/10.1080/23311916.2016.1167990

[5] Memon, Saim. "Advanced Thermoelectric Materials for Energy Harvesting Applications." .IntechOpen Publisher, London, ISBN: 978-1-78984-529-7, (2020). https://doi.org/10.5772/intechopen.77430

[6] Memon, Saim, and Khawaja Noman Tahir. "Experimental and analytical simulation analyses on the electrical performance of thermoelectric generator modules for direct and concentrated quartz-halogen heat harvesting." Energies 11, no. 12 (2018): 3315.

https://doi.org/10.3390/en11123315

[7] Chen, Zhen, Linxiao Zhu, Wei Li, and Shanhui Fan. "Simultaneously and synergistically harvest energy from the sun and outer space." Joule 3, no. 1 (2019): 101-110.

https://doi.org/10.1016/j.joule.2018.10.009

[8] Jamar, A. M. Z. A. A., Z. A. A. Majid, W. H. Azmi, M. Norhafana, and A. A. Razak. "A review of water heating system for solar energy applications." International Communications in Heat and Mass Transfer 76 (2016): 178-187. https://doi.org/10.1016/j.icheatmasstransfer.2016.05.028

[9] IEA SHC. "Solar Heat Worldwide-Global Market Development and Trends in 2019." AEE-INTEC, Austria. Accessed May $29 \quad$ (2020). https://www.iea-shc.org/solar-heatworldwide\#: :text=In\%20total\%2C\%20more\%20than\%20800,a\%20capacity\%20of\%20700\%20MWth

[10] Hudon, Kate. "Solar Energy-Water Heating." In Future Energy, pp. 433-451. Elsevier, 2014. https://doi.org/10.1016/B978-0-08-099424-6.00020-X.

[11] Tian, Yuan, and Chang-Ying Zhao. "A review of solar collectors and thermal energy storage in solar thermal applications." Applied energy 104 (2013): 538-553. https://doi.org/10.1016/j.apenergy.2012.11.051

[12] Sabiha, M. A., R. Saidur, Saad Mekhilef, and Omid Mahian. "Progress and latest developments of evacuated tube solar collectors." Renewable and Sustainable Energy Reviews 51 (2015): 1038-1054. https://doi.org/10.1016/j.rser.2015.07.016

[13] Benz, N., and T. Beikircher. "High efficiency evacuated flat-plate solar collector for process steam production." Solar Energy 65, no. 2 (1999): 111-118. https://doi.org/10.1016/S0038-092X(98)00122-4

[14] Elsheniti, Mahmoud B., Amr Kotb, and Osama Elsamni. "Thermal performance of a heat-pipe evacuated-tube solar collector at high inlet temperatures." Applied Thermal Engineering 154 (2019): 315-325. https://doi.org/10.1016/j.applthermaleng.2019.03.106

[15] Shah, Louise Jivan, and Simon Furbo. "Vertical evacuated tubular-collectors utilizing solar radiation from all directions." Applied energy 78, no. 4 (2004): 371-395. https://doi.org/10.1016/j.apenergy.2003.10.004

[16] Yazdanifard, Farideh, Ehsan Ebrahimnia-Bajestan, and Mehran Ameri. "Investigating the performance of a waterbased photovoltaic/thermal (PV/T) collector in laminar and turbulent flow regime." Renewable Energy 99 (2016): 295-306. 
https://doi.org/10.1016/j.renene.2016.07.004

[17] Bergene, Trond, and Ole Martin Løvvik. "Model calculations on a flat-plate solar heat collector with integrated solar cells." Solar energy 55, no. 6 (1995): 453-462. https://doi.org/10.1016/0038-092X(95)00072-Y

[18] Kalogirou, Soteris A. "Use of TRNSYS for modelling and simulation of a hybrid pv-thermal solar system for Cyprus." Renewable energy 23, no. 2 (2001): 247-260. https://doi.org/10.1016/S0960-1481(00)00176-2

[19] Agarwal, Ram Kumar, and H. P. Garg. "Study of a photovoltaic-thermal system-Thermosyphonic solar water heater combined with solar cells." Energy Conversion and Management 35, no. 7 (1994): 605-620. https://doi.org/10.1016/0196-8904(94)90044-2

[20] Fujisawa, Toru, and Tatsuo Tani. "Optimum design for residential photovoltaic-thermal binary utilization system by minimizing auxiliary energy." Electrical Engineering in Japan 137, no. 1 (2001): 28-35. https://doi.org/10.1002/eej.1077

[21] Tonui, J. K., and Y. Tripanagnostopoulos. "Improved PV/T solar collectors with heat extraction by forced or natural air circulation." Renewable energy 32, no. 4 (2007): 623-637. https://doi.org/10.1016/j.renene.2006.03.006

[22] Hegazy, Adel A. "Comparative study of the performances of four photovoltaic/thermal solar air collectors." Energy Conversion and management 41, no. 8 (2000): 861-881. https://doi.org/10.1016/S0196-8904(99)00136-3

[23] Makki, Adham, Siddig Omer, Yuehong Su, and Hisham Sabir. "Numerical investigation of heat pipe-based photovoltaic-thermoelectric generator (HP-PV/TEG) hybrid system." Energy conversion and management 112 (2016): 274-287. https://doi.org/10.1016/j.enconman.2015.12.069

[24] Diwania, Sourav, Sanjay Agrawal, Anwar S. Siddiqui, and Sonveer Singh. "Photovoltaic-thermal (PV/T) technology: a comprehensive review on applications and its advancement." International Journal of Energy and Environmental Engineering 11, no. 1 (2020): 33-54. https://doi.org/10.1007/s40095-019-00327-y

[25] Bell, Lon E. "Cooling, heating, generating power, and recovering waste heat with thermoelectric systems." Science 321, no. 5895 (2008): 1457-1461. https://doi.org/10.1126/science.1158899

[26] Babu, Challa, and P. Ponnambalam. "The role of thermoelectric generators in the hybrid PV/T systems: A review." Energy conversion and management 151 (2017): 368-385. https://doi.org/10.1016/j.enconman.2017.08.060

[27] Radwan, Ali, Mahmoud Ahmed, and Shinichi Ookawara. "Performance enhancement of concentrated photovoltaic systems using a microchannel heat sink with nanofluids." Energy Conversion and Management 119 (2016): 289303. https://doi.org/10.1016/j.enconman.2016.04.045

[28] Radwan, Ali, Shinichi Ookawara, Shinsuke Mori, and Mahmoud Ahmed. "Uniform cooling for concentrator photovoltaic cells and electronic chips by forced convective boiling in 3D-printed monolithic double-layer microchannel heat sink." Energy conversion and management 166 (2018): 356-371. https://doi.org/10.1016/j.enconman.2018.04.037

[29] Radwan, Ali, and Mahmoud Ahmed. "The influence of microchannel heat sink configurations on the performance of low concentrator photovoltaic systems." Applied energy 206 (2017): 594-611. https://doi.org/10.1016/j.apenergy.2017.08.202

[30] Awad, Mohamed, Ali Radwan, O. Abdelrehim, Mohamed Emam, Ahmed N. Shmroukh, and Mahmoud Ahmed. "Performance evaluation of concentrator photovoltaic systems integrated with a new jet impingementmicrochannel heat sink and heat spreader." Solar Energy 199 (2020): 852-863. https://doi.org/10.1016/j.solener.2020.02.078

[31] Cabrera, F. J., A. Fernández-García, R. M. P. Silva, and M. Pérez-García. "Use of parabolic trough solar collectors for solar refrigeration and air-conditioning applications." Renewable and Sustainable Energy Reviews 20 (2013): 103118. https://doi.org/10.1016/j.rser.2012.11.081

[32] Mohamad, A., J. Orfi, and H. Alansary. "Heat losses from parabolic trough solar collectors." International journal of energy research 38, no. 1 (2014): 20-28. https://doi.org/10.1002/er.3010 
[33] Islam, Md Tasbirul, Nazmul Huda, A. B. Abdullah, and R. Saidur. "A comprehensive review of state-of-the-art concentrating solar power (CSP) technologies: Current status and research trends." Renewable and Sustainable Energy Reviews 91 (2018): 987-1018. https://doi.org/10.1016/j.rser.2018.04.097

[34] Duddu, P. "The world's biggest solar power plants". Accessed June 1 (2020). http://www.powertechnology.com/features/feature-largest-solar-power-plants-in-the-world/

[35] Hafez, A. Z., Ahmed Soliman, K. A. El-Metwally, and I. M. Ismail. "Solar parabolic dish Stirling engine system design, simulation, and thermal analysis." Energy Conversion and Management 126 (2016): 60-75. https://doi.org/10.1016/j.enconman.2016.07.067

[36] Dafle, Vishal R., and N. N. Shinde. "Design, development \& performance evaluation of concentrating monoaxial Scheffler technology for water heating and low temperature industrial steam application." International Journal of Engineering Research and Applications 2, no. 6 (2012): 1179-1186.

[37] Lovegrove, Keith, Gregory Burgess, and John Pye. "A new 500 m2 paraboloidal dish solar concentrator." Solar Energy 85, no. 4 (2011): 620-626.

https://doi.org/10.1016/j.solener.2010.01.009

[38] Sup, Billy Anak, Mohd Farid Zainudin, Tanti Zanariah Shamsir Ali, Rosli Abu Bakar, and Gan Leong Ming. "Effect of rim angle to the flux distribution diameter in solar parabolic dish collector." Energy procedia 68 (2015): 45-52. https://doi.org/10.1016/j.egypro.2015.03.231

[39] Reinalter, Wolfgang, Steffen Ulmer, Peter Heller, Thorsten Rauch, J-M. Gineste, Alain Ferriere, and Francois Nepveu. "Detailed performance analysis of a 10kW dish stirling system." Journal of Solar Energy Engineering 130, no. 1 (2008).

https://doi.org/10.1115/1.2807191

[40] Coventry, Joe, and Charles Andraka. "Dish systems for CSP." Solar Energy 152 (2017): 140-170. https://doi.org/10.1016/j.solener.2017.02.056

[41] Muthusivagami, R. M., R. Velraj, and R. Sethumadhavan. "Solar cookers with and without thermal storage-a review." Renewable and Sustainable Energy Reviews 14, no. 2 (2010): 691-701. https://doi.org/10.1016/j.rser.2008.08.018

[42] Breeze, Paul. " Power generation technologies ". Newnes, 2019. https://doi.org/10.1016/B978-0-08-102631-1.00013-4

[43] Wang, Zhifeng. "Introduction-Design of Solar Thermal Power Plants". Academic Press, 2019. https://doi.org/10.1016/B978-0-12-815613-1.00001-8

[44] Qazi, Salahuddin. "Solar Thermal Electricity and Solar Insolation- Standalone Photovoltaic (PV) Systems for Disaster Relief and Remote Areas". Elsevier, 2017. https://doi.org/10.1016/B978-0-12-803022-6.00007-1

[45] Zhu, Guangdong, Tim Wendelin, Michael J. Wagner, and Chuck Kutscher. "History, current state, and future of linear Fresnel concentrating solar collectors." Solar Energy 103 (2014): 639-652. https://doi.org/10.1016/j.solener.2013.05.021

[46] Sahoo, Sudhansu S., Suneet Singh, and Rangan Banerjee. "Analysis of heat losses from a trapezoidal cavity used for Linear Fresnel Reflector system." Solar Energy 86, no. 5 (2012): 1313-1322. https://doi.org/10.1016/j.solener.2012.01.023

[47] IEA. "World Energy Statistics and Balances 2019 (database)". Accessed June 2 (2020). www.iea.org/statistics. Energy Technology Perspectives, buildings model. www.iea.org/buildings

[48] GlobalABC-IEA. "Global Status Report for Buildings and Construction-Towards a zero-emissions, efficient and resilient buildings and construction sector", ISBN No: 978-92-807-3768-4. Accessed June 3 (2020). https://www.worldgbc.org/news-media/2019-global-status-report-buildings-and-construction

[49] Memon, Saim, Yueping Fang, and Philip C. Eames. "The influence of low-temperature surface induction on evacuation, pump-out hole sealing and thermal performance of composite edge-sealed vacuum insulated glazing." Renewable energy 135 (2019): 450-464. https://doi.org/10.1016/j.renene.2018.12.025

[50] Weston, G.F., 2013. Ultrahigh vacuum practice. Elsevier.

[51] Collins, R. E., and T. M. Simko. "Current status of the science and technology of vacuum glazing." Solar Energy 62, no. 3 (1998): 189-213. https://doi.org/10.1016/S0038-092X(98)00007-3

[52] Griffiths, P. W., Mariella di Leo, Peter Cartwright, P. C. Eames, P. Yianoulis, G. Leftheriotis, and Brian Norton. "Fabrication of evacuated glazing at low temperature." Solar Energy 63, no. 4 (1998): 243-249. https://doi.org/10.1016/S0038-092X(98)00019-X 
[53] Fischer-Cripps, Anthony Craig, R. E. Collins, G. M. Turner, and E. Bezzel. "Stresses and fracture probability in evacuated glazing." Building and environment 30, no. 1 (1995): 41-59. https://doi.org/10.1016/0360-1323(94)E0032-M

[54] Fang, Yueping, Philip C. Eames, Brian Norton, and Trevor J. Hyde. "Experimental validation of a numerical model for heat transfer in vacuum glazing." Solar Energy 80, no. 5 (2006): 564-577. https://doi.org/10.1016/j.solener.2005.04.002

[55] Wilson, C. F., T. M. Simko, and R. E. Collins. "Heat conduction through the support pillars in vacuum glazing." Solar Energy 63, no. 6 (1998): 393-406. https://doi.org/10.1016/S0038-092X(98)00079-6

[56] Koebel, Matthias M., Heinrich Manz, Karl Emanuel Mayerhofer, and Beat Keller. "Service-life limitations in vacuum glazing: A transient pressure balance model." Solar energy materials and solar cells 94, no. 6 (2010): 1015-1024. https://doi.org/10.1016/j.solmat.2010.02.003

[57] Memon, Saim. "Design, fabrication and performance analysis of vacuum glazing units fabricated with low and high temperature hermetic glass edge sealing materials." PhD diss., Loughborough University, 2013. https://dspace.lboro.ac.uk/2134/14562

[58] Collins, R. E., and S. J. Robinson. "Evacuated glazing." Solar Energy 47, no. 1 (1991): 27-38. https://doi.org/10.1016/0038-092X(91)90060-A

[59] Benson, David K., C. Edwin Tracy, and Gary J. Jorgensen. "Laser sealed evacuated window glazings." In Optical Materials Technology for Energy Efficiency and Solar Energy Conversion III, vol. 502, pp. 146-151. International Society for Optics and Photonics, 1984.

[60] Wang, J., P. C. Eames, J. F. Zhao, Trevor Hyde, and Yueping Fang. "Stresses in vacuum glazing fabricated at low temperature." Solar energy materials and solar cells 91, no. 4 (2007): 290-303. https://doi.org/10.1016/j.solmat.2006.10.007

[61] Fang, Yueping, Trevor Hyde, Neil Hewitt, Philip C. Eames, and Brian Norton. "Comparison of vacuum glazing thermal performance predicted using two-and three-dimensional models and their experimental validation." Solar Energy Materials and Solar Cells 93, no. 9 (2009): 1492-1498. https://doi.org/10.1016/j.solmat.2009.03.025

[62] Robinson, S. J., and R. E. Collins. "Evacuated windows-theory and practice." In ISES solar world congress, international solar energy society, Kobe, Japan. 1989.

[63] Collins, R. E., A. C. Fischer-Cripps, and J-Z. Tang. "Transparent evacuated insulation." Solar Energy 49, no. 5 (1992): 333-350. https://doi.org/10.1016/0038-092X(92)90106-K

[64] Garrison, J. D., and R. E. Collins. "Manufacture and cost of vacuum glazing." Solar Energy 55, no. 3 (1995): $151-161$. https://doi.org/10.1016/0038-092X(95)00046-T

[65] Uhlmann, D., ed. Elasticity and Strength in Glasses: Glass: Science and Technology. Vol. 5. Elsevier, 2012.

[66] Memon, Saim, Farukh Farukh, and Karthikeyan Kandan. "Effect of cavity vacuum pressure diminution on thermal performance of triple vacuum glazing." Applied Sciences 8, no. 9 (2018): 1705. https://doi.org/10.3390/app8091705

[67] Griffiths, Philip W., Philip C. Eames, Trevor J. Hyde, Yueping Fang, and Brian Norton. "Experimental characterization and detailed performance prediction of a vacuum glazing system fabricated with a low temperature metal edge seal, using a validated computer model." (2006): 199-203. https://doi.org/10.1115/1.2188529

[68] Zhao, Jun Fu, Philip C. Eames, Trevor J. Hyde, Yueping Fang, and Jinlei Wang. "A modified pump-out technique used for fabrication of low temperature metal sealed vacuum glazing." Solar Energy 81, no. 9 (2007): 1072-1077. https://doi.org/10.1016/j.solener.2007.03.006

[69] Fang, Yueping, Trevor J. Hyde, Farid Arya, Neil Hewitt, Philip C. Eames, Brian Norton, and Seth Miller. "Indium alloysealed vacuum glazing development and context." Renewable and Sustainable Energy Reviews 37 (2014): $480-501$. https://doi.org/10.1016/j.rser.2014.05.029

[70] Memon, Saim. "Experimental measurement of hermetic edge seal's thermal conductivity for the thermal transmittance prediction of triple vacuum glazing." Case studies in thermal engineering 10 (2017): 169-178. https://doi.org/10.1016/j.csite.2017.06.002

[71] Memon, Saim, Farukh Farukh, Philip C. Eames, and Vadim V. Silberschmidt. "A new low-temperature hermetic composite edge seal for the fabrication of triple vacuum glazing." Vacuum 120 (2015): 73-82. https://doi.org/10.1016/j.vacuum.2015.06.024

[72] Memon, Saim, and Philip C. Eames. "Predicting the solar energy and space-heating energy performance for solidwall detached house retrofitted with the composite edge-sealed triple vacuum glazing." Energy Procedia 122 (2017): 565-570. 
https://doi.org/10.1016/j.egypro.2017.07.419

[73] Memon, Saim. "Analysing the potential of retrofitting ultra-low heat loss triple vacuum glazed windows to an existing UK solid wall dwelling." International Journal of Renewable Energy Development (IJRED) 3, no. 3 (2014): 161-174. https://doi.org/10.14710/ijred.3.3.161-174

[74] Memon, Saim, and Philip C. Eames. "Heat load and solar gain prediction for solid wall dwellings retrofitted with triple vacuum glazing for selected window to wall area ratios." In World Renewable Energy Forum, WREF 2012, vol. 6, pp. 4636-4643. ASES, 2012. ISBN: 9781622760923

[75] Fang, Yueping, Saim Memon, Jingqing Peng, Mark Tyrer, and Tingzhen Ming. "Solar thermal performance of two innovative configurations of air-vacuum layered triple glazed windows." Renewable Energy 150 (2020): 167-175. https://doi.org/10.1016/j.renene.2019.12.115

[76] Memon, Saim, and Philip C. Eames. "Solar energy gain and space-heating energy supply analyses for solid-wall dwelling retrofitted with the experimentally achievable U-value of novel triple vacuum glazing." Journal of Daylighting 4, no. 1 (2017): 15-25.

https://doi.org/10.15627/jd.2017.2

[77] Memon, Saim. "Thermal Conductivity Measurement of Vacuum Tight Dual-Edge Seal for the Thermal Performance Analysis of Triple Vacuum Glazing." Impact of Thermal Conductivity on Energy Technologies (2018): 133. http://dx.doi.org/10.5772/intechopen.74255

[78] Memon, Saim. "Design, development and thermal performance analysis of ultra-low heat loss triple vacuum glazing." In Solar World Congress 2017-Innovation for the 100\% renewable energy transformation. London South Bank University, 2017.

https://doi.org/10.18086/swc.2017.15.04

[79] Memon, Saim. "Investigating energy saving performance interdependencies with retrofit triple vacuum glazing for use in UK dwelling with solid walls, Sustainable Development on Building and Environment." In Sustainable Development on Building and Environment: Proceedings of the 7th International Conference, 2015. ISBN-13: 9780993120701.

[80] Miao, Hong, Lingcong Zhang, Sixing Liu, Shanwen Zhang, Saim Memon, and Bi Zhu. "Laser Sealing for Vacuum Plate Glass with PbO-TiO2-SiO2-RxOy Solder." Sustainability 12, no. 8 (2020): 3118. https://doi.org/10.3390/su12083118

[81] Zhang, Shanwen, Min Kong, Saim Memon, Hong Miao, Yanjun Zhang, and Sixing Liu. "Thermal Analysis of a New Neutron Shielding Vacuum Multiple Glass." Sustainability 12, no. 8 (2020): 3083. https://doi.org/10.3390/su12083083

[82] Katsura, Takao, Ali Radwan, Zhang Yang, Makoto Nakamura, and Katsunori Nagano. "Energy conservation using new structured-core and transparent vacuum insulation panels: Numerical simulation with experimental validation." Solar Energy 193 (2019): 885-905.

https://doi.org/10.1016/j.solener.2019.09.083

[83] Boafo, Fred Edmond, Jin-Hee Kim, and Jun-Tae Kim. "Numerical study of slim curtain wall spandrel with integrated vacuum insulation panel: Concept, performance evaluation and challenges." Energy and Buildings 183 (2019): 139150.

https://doi.org/10.1016/j.enbuild.2018.10.036

[84] Fricke, J., U. Heinemann, and H. P. Ebert. "Vacuum insulation panels-From research to market." Vacuum 82, no. 7 (2008): 680-690. https://doi.org/10.1016/j.vacuum.2007.10.014

[85] Katsura, Takao, Saim Memon, Ali Radwan, Makoto Nakamura, and Katsunori Nagano. "Thermal performance analysis of a new structured-core translucent vacuum insulation panel in comparison to vacuum glazing: Experimental and theoretically validated analyses." Solar Energy 199 (2020): 326-346. https://doi.org/10.1016/j.solener.2020.02.030

[86] Khan, Asif, Saim Memon, and Tariq Pervez Sattar. "Analyzing integrated renewable energy and smart-grid systems to improve voltage quality and harmonic distortion losses at electric-vehicle charging stations." IEEE Access 6 (2018): 26404-26415. https://doi.ord/10.1109/ACCESS.2018.2830187

[87] Khan, Asif, Saim Memon, and Tariq Sattar. "Integration and management of solar energy for electric vehicle charging station." (2017). https://doi.org/10.18086/swc.2017.16.03

[88] Radwan, Ali, Takao Katsura, Saim Memon, Ahmed A. Serageldin, Makoto Nakamura, and Katsunori Nagano. "Thermal and electrical performances of semi-transparent photovoltaic glazing integrated with translucent vacuum insulation panel and vacuum glazing." Energy Conversion and Management 215 (2020): 112920. 
https://doi.org/10.1016/j.enconman.2020.112920

[89] Hoseinzadeh, Siamak, and Reza Azadi. "Simulation and optimization of a solar-assisted heating and cooling system for a house in Northern of Iran." Journal of Renewable and Sustainable Energy 9, no. 4 (2017): 045101. https://doi.org/10.1063/1.5000288

[90] Hoseinzadeh, Siamak, Mohammad Hadi Zakeri, Atoosa Shirkhani, and Ali J. Chamkha. "Analysis of energy consumption improvements of a zero-energy building in a humid mountainous area." Journal of Renewable and Sustainable Energy 11, no. 1 (2019): 015103.

https://doi.org/10.1063/1.5046512 